\title{
ANALISIS KESALAHAN DALAM MENYELESAIKAN SOAL PERSAMAAN GARIS LURUS PADA SISWA KELAS VIII-2 MTS NEGERI 2 KENDARI
}

\author{
Rismala Dewi ${ }^{\text {1) }}$, Lambertus ${ }^{2)}$, Hafiludin S. ${ }^{3)}$ \\ ${ }^{1)}$ Alumni Jurusan Pendidikan Matematika, ${ }^{2,3)}$ Dosen Jurusan Pendidikan Matematika \\ FKIP UHO. email: immhaquincy@gmail.com; lambertus_59@yahoo.co.id; \\ hafiludin79@yahoo.com
}

\begin{abstract}
Abstrak
Penelitian ini adalah penelitian eksploratif, metode yang digunakan metode deskriptif kualitatif. Subjek dalam penelitian ini adalah kelas VIII-2 MTs Negeri 2 Kendari sebanyak 29 orang, dan subjek yang diwawancarai dalam penelitian ini terdiri dari 3 orang. Analisis data dilakukan melalui reduksi data, penyajian data, dan penarikan kesimpulan dan verifikasi data. Validasi data dilakukan dengan triangulasi data. Data tentang kesalahan masing-masing subjek diperoleh dari tes. Jawaban siswa dianalisis untuk mendapatkan kesalahan-kesalahan dalam menyelesaikan soal Persamaan Garis Lurus. Hasil yang diperoleh dalam penelitian ini adalah: (1) jenis kesalahan yang dilakukan siswa dalam menyelesaikan soal Persamaan Garis Lurus yaitu kesalahan menginterpretasi bahasa, kesalahan konsep, kesalahan prinsip dan kesalahan dalam keterampilan, (2) penyebab siswa melakukan kesalahan dalam menyelesaikan soal Persamaan Garis Lurus adalah siswa tidak memahami konsep, siswa tidak dapat menggabungkan konsep-konsep yang diperlukan dalam menyelesaikan soal, dan faktor keteledoran siswa, siswa tidak memahami maksud soal dan langkahlangkah untuk menyelesaikan soal.
\end{abstract}

Kata Kunci: analisis kesalahan; menyelesaikan soal; persamaan garis lurus

\section{ANAL YSIS OF ERRORS IN RESOLVING PROBLEMS IN STRAIGHT LINE EQUATION OF CLASS VIII-2 MTS NEGERI 2 KENDARI}

\begin{abstract}
This research is exploratory research, the method used is descriptive qualitative method. The subjects in this study were class VIII-2 MTs Negeri 2 Kendari as many as 29 people, and the subjects interviewed in this study consisted of 3 people. Data analysis is done through data reduction, data presentation, and conclusion and data verification. Data validation is done by data triangulation. Data about the errors of each subject was obtained from the test. Student answers are analyzed to get errors in solving problems with Straight Line Equations. The results obtained in this study are: (1) the types of errors students make in solving Straight Line Equations questions that are errors in interpreting languages, conceptual errors, principle errors and skill errors, (2) causes students to make mistakes in solving Straight Line Equations is that students do not understand the concept, students cannot combine the concepts needed to solve the problem, and the factors of neglect of students, students do not understand the intent of the problem and the steps to solve the problem.
\end{abstract}

Keywords: analysis of error; resolving problems; equation straight line 


\section{Pendahuluan}

Matematika merupakan salah satu bidang ilmu yang perlu ditingkatkan penguasaannya bagi setiap peserta didik, sebab matematika merupakan dasar dari ilmu pengetahuan yang lain, khususnya bagi pengembangan ilmu pengetahuan dan teknologi. Matematika terus mengalami perkembangan baik dalam segi teori maupun segi penerapannya. Sebagai ilmu dasar, matematika digunakan secara luas dalam segala bidang kehidupan manusia, sehingga diperlukan suatu upaya dalam pengajaran matematika agar dapat terlaksana secara optimal sehingga setiap siswa dapat memahami matematika dengan baik.

Materi matematika yang diajarkan pada jenjang SMP sangat beragam, diantaranya operasi bilangan bulat, aljabar, geometri, himpunan, fungsi dan relasi. Dari beberapa jenis materi yang diajarkan di SMP, satu diantaranya adalah materi persamaan garis lurus. Dalam materi persamaan garis lurus, terdapat beberapa sub materi diantaranya menggambar grafik persamaan garis lurus, gradien garis, dan menentukan persamaan garis.

Persamaan garis banyak diterapkan dalam bidang ilmu lain. Seperti yang dinyatakan oleh Dris (2011) bahwa beberapa perumusan fisika dinyatakan dalam bentuk persamaan garis lurus, misalnya kecepatan yang dirumuskan dengan $V=V_{o}+$ at yang merupakan bentuk persamaan garis lurus, dan juga hukum Ohm yang menyatakan hubungan antara tegangan $(V)$ dan arus listrik $(i)$ dengan rumus $V=i \times r$ dinyatakan dalam persamaan garis lurus. Selain itu terdapat aplikasi persamaan garis lurus dalam kehidupan sehari-hari, diantaranya menghitung kemiringan pembuatan tangga yang aman, mengetahui hubungan antara kecepatan dan waktu yang dibutuhkan saat berkendara, menghitung perkembangan produksi suatu barang (Rahaju, 2008). Oleh karena itu, penting bagi siswa untuk menguasai konsep persamaan garis lurus.

Namun kenyataan yang dijumpai pada siswa kelas VIII di MTs Negeri 2 Kendari masih banyak melakukan kesalahan dalam menyelesaikan soal-soal persamaan garis lurus. Berdasarkan hasil observasi awal/wawancara dengan guru bidang studi matematika mengungkapkan bahwa siswa masih sering melakukan kesalahan dalam menyelesaikan soal matematika, begitu pula pada soal persamaan garis lurus. Siswa tidak menguasai konsep dasar persamaan garis lurus, menggambar garis persamaan garis lurus pada bidang cartesius. Selain itu siswa juga kadang melakukan kesalahan dalam menerapkan rumus untuk menyelesaikan soal persamaan garis lurus, hal ini disebabkan karena siswa tidak menguasai konsep aljabar dan konsep dari persamaan garis lurus tersebut. Masih ada juga siswa yang tidak menguasai konsep operasi bilangan bulat, dan sistem koordinat sehingga siswa salah dalam proses perhitungannya. Materi-materi ini semua merupakan prasyarat untuk materi persamaan garis lurus yang kebanyakan siswa belum menguasainya.

Berdasarkan uraian yang telah dikemukakan di atas, penulis tertarik untuk menganalisis kesalahan-kesalahan siswa dalam menyelesaikan soal Garis Singgung Persekutuan Dua Lingkaran dan mengidentifikasi kesalahankesalahan pengerjaan soal yang dikerjakan siswa, yang dituangkan dalam sebuah judul "Analisis Kesalahan dalam Menyelesaikan Soal Garis Singgung Persekutuan Dua Lingkaran pada Siswa Kelas VIII-8 Semester II MTs Negeri 1 Kendari”.

Tujuan dalam penelitian ini adalah sebagai berikut:

1. Untuk mengetahui jenis kesalahan yang dilakukan siswa kelas VIII-2 MTs Negeri 2 Kendari dalam menyelesaikan soal Persamaan Garis Lurus.

2. Untuk mengetahui penyebab siswa melakukan kesalahan dalam menyelesaikan soal Persamaan Garis Lurus.

Gagne (1983) telah membagi objekobjek matematika yang diperoleh siswa menjadi objek langsung dan objek tak langsung. Objek langsung terdiri dari fakta (fact), konsep (concept), prinsip (principle), dan keterampilan (skill). Sedangkan contoh objek tak langsungnya adalah berpikir logis, kemampuan memecahkan masalah, sikap positif terhadap matematika, ketekunan dan ketelitian. Jadi, objek tak langsung adalah kemampuan yang secara tak langsung akan dipelajari siswa ketika mereka mempelajari objek langsung matematika. Untuk

\section{8}


lebih jelasnya objek-objek matematika ini diuraikan sebagai berikut:

a. Fakta

Fakta adalah pemufakatan atau konvensi dalam matematika yang biasanya diungkapkan melalui simbol-simbol tertentu (Fathani, 2009:59)

b. Konsep

Konsep adalah ide abstrak yang digunakan untuk menggolongkan atau mengkategorikan sekumpulan obyek ke dalam contoh dan bukan contoh (Fathani, 2009:61).

c. Prinsip

Prinsip (keterkaitan antar konsep) adalah suatu gagasan yang memuat hubungan antara dua konsep atau lebih. Seorang siswa dinyatakan telah mampu memahami suatu prinsip jika ia: (1) ingat rumus atau prinsip yang bersesuaian; (2) memahami seberapa konsep yang digunakan serta lambang atau notasinya; dan (3) dapat menggunakan rumus atau prinsip yang bersesuaian pada situasi yang tepat. (Shadiq, 2011:14)

c. Keterampilan (skill)

Keterampilan (skill) adalah kemampuan untuk menggunakan prosedur atau langkahlangkah untuk menyelesaikan suatu soal. Istilah yang sering digunakan juga adalah algoritma yang berarti langkah-langkah standar untuk menyelesaikan soal. Pada pembelajaran keterampilan (skill) penekanannya adalah pada kemampuan untuk menggunakan urut-urutan, prosedur atau langkah-langkah pengerjaan. Seorang siswa akan disebut memahami suatu keterampilan (skill) jika ia dapat menggunakan urut-urutan, prosedur, atau langkah-langkah pengerjaan (Shadiq, 2011;14-15)

Kesalahan-kesalahan dalam menyelesaikan soal persamaan garis lurus, yaitu :

1. Kesalahan Menginterpretasi Bahasa

Kesalahan yang terjadi dalam aspek ini seringkali disebabkan karena siswa tidak teliti dalam membaca soal dan siswa tidak mampu memahami simbol-simbol yang harus digunakan sehingga jawaban yang diperoleh siswa seringkali tidak sesuai dengan apa yang diharapkan. Kesalahan yang berkaitan dengan fakta adalah kesalahan menggunakan simbol.

2. Kesalahan Konsep

Kesalahan ini erat kaitannya dengan penguasaan materi yang dimiliki oleh siswa. Dari penguasaan materi yang telah dimiliki, siswa diharapkan dapat menggunakan pemahaman konsep yang dimilikinya tersebut untuk menyelesaikan persoalan yang sedang dihadapi. Kesalahan dalam memahami konsep adalah kesalahan yang dilakukan siswa karena lemahnya konsep yang dikuasai oleh siswa. Kesalahan yang berkaitan dengan konsep: (1) Kesalahan mendefinisikan konsep; (2) Penggunaan ilustrasi yang kurang sesuai untuk menjelaskan konsep.

3. Kesalahan Prinsip

Jika siswa tidak benar-benar memahami konsep-konsep yang akan digunakan untuk menyelesaiakan soal, maka siswa akan melakukan kesalahan dalam menerapkan beberapa konsep tersebut. Kesalahan yang berkaitan dengan prinsip adalah kesalahan menghubungkan beberapa konsep atau fakta dengan konsep.

4. Kesalahan dalam keterampilan

Kesalahan dalam keterampilan yaitu siswa melakukan kesalahan dalam menggunakan prosedur atau langkah-langkah penyelesaian soal. Kesalahan yang berkaitan dengan keterampilan: (1) Informasi pada proses pengerjaan tidak sama dengan informasi awal soal; (2) Kesalahan dalam proses penghitungan; (3) Kesalahan dalam proses pengerjaan.

\section{Metode Penelitian}

Penelitian ini dilaksanakan di MTs Negeri 2 Kendari dan waktu pelaksanaan penelitian ini pada semester ganjil Tahun Ajaran 2018/2019. Untuk keperluan penelitian ini, kelas yang menjadi subjek penelitian yaitu kelas VIII2. Pengambilan kelas dalam penelitian ini dilakukan berdasarkan pertimbangan bahwa kelas VIII-2 adalah kelas yang mempunyai nilai rata-rata sedang jika dibandingkan dengan kelaskelas yang lain.

Untuk menentukan siswa yang terpilih sebagai subjek penelitian yang diwawancarai dalam penelitian ini digunakan teknik purposive sampling, yaitu penelitian yang menggunakan teknik penentuan subjek dengan kriteria tertentu (purposif). Adapun kriteria penentuan subjek penelitian yang akan diwawancara adalah:

1. Memperhatikan jumlah kesalahan siswa dalam menjawab soal, yaitu satu siswa dengan kategori jumlah kesalahan tinggi, satu siswa dengan kategori jumlah 
kesalahan sedang dan satu siswa dengan kategori jumlah kesalahan rendah.

2. Memperhatikan kesalahan atau variasi kesalahan yang dilakukan siswa, berupa kesalahan menginterpretasi bahasa, konsep, prinsip dan keterampilan.

Penelitian ini adalah penelitian kualitatif sehingga yang menjadi instrumen kunci sebagai pengumpul data utama adalah peneliti sendiri. Hal ini sejalan dengan yang dikemukakan oleh Biklen (1982) bahwa manusia merupakan alat (instrumen) utama pengumpul data. Akan tetapi dalam penelitian ini juga digunakan instrumen lain sebagai pelengkap, yaitu observasi, dokumentasi, tes dan wawancara.

Teknik pengumpulan data yang dilakukan dalam penelitian ini adalah: (1) observasi; (2) dokumentasi; (3) pemberian tes; (4) wawancara.

1. Observasi

Observasi adalah cara menghimpun bahan-bahan keterangan atau data yang dilakukan dengan mengadakan pengamatan dan pencatatan secara sistematis terhadap fenomenafenomena yang sedang dijadikan sasaran pengamatan (Sudijono, 2006:76). Observasi pada penelitian ini dilakukan pada saat berlangsungnya proses belajar mengajar. Observasi dalam penelitian ini dilakukan untuk mengetahui aktivitas siswa dan guru serta interaksi antara siswa dan guru dalam proses belajar mengajar pada materi persamaan garis lurus. Observasi ini dilakukan sebanyak 5 kali pertemuan.

\section{Dokumentasi}

Budiyono (2003:54) mengungkapkan bahwa metode dokumentasi adalah cara pengumpulan data dengan melihatnya dalam dokumen-dokumen yang telah ada. Dokumendokumen tersebut biasanya merupakan dokumen resmi yang telah terjamin keakuratannya. Dalam penelitian ini metode dokumentasi dilakukan untuk mendapatkan data tentang data kelas dan nama-nama siswa yang menjadi subyek penelitian.

\section{Pemberian tes}

Tes merupakan himpunan pertanyaan yang harus dijawab, harus ditanggapi, atau tugas yang harus dilaksanakan oleh orang yang dites (Sudaryono, 2012:101). Bentuk tes yang digunakan dalam penelitian ini adalah tes tertulis yang berbentuk uraian. Tes disusun oleh peneliti dan dikonsultasikan ke dosen pembimbing dan guru matematika. Pemberian tes ini dimaksudkan untuk memperoleh hasil pekerjaan siswa sehingga diperoleh gambaran tentang jenis kesalahan yang dilakukan siswa dalam menyelesaiakn soal persamaan garis lurus. Pemberian tes ini dilakukan setelah selesai materi persamaan garis lurus yaitu pada hari Jumat, 26 Oktober 2018.

\section{Wawancara}

Wawancara merupakan salah satu teknik pengumpulan data yang dilakukan dengan cara mengadakan tanya jawab baik secara langsung maupun tidak langsung dengan sumber data (Sudjana, 2008: 68). Metode wawancara digunakan untuk melengkapi data tentang jenis kesalahan yang dilakukan oleh peserta didik yang diperoleh melalui jawaban soal tes tertulis berbentuk uraian.

Prosedur yang dilakukan untuk memperoleh data dalam penelitian ini yaitu sebagai berikut:

1. Melakukan observasi pada saat proses pembelajaran materi persamaan garis lurus. Observasi dalam penelitian ini dilakukan untuk mengetahui aktivitas siswa dan guru serta interaksi antara siswa dan guru dalam proses pembelajaran.

2. Pemberian tes pada kelas yang menjadi sasaran penelitian. Tes bertujuan untuk mengetahui lebih awal tentang deskripsi kesalahan-kesalahan siswa dalam menyelesaikan soal-soal persamaan garis lurus. Pemberian tes ini dilakukan setelah selesai materi Persamaan garis lurus.

3. Melakukan wawancara dengan siswa. Wawancara bertujuan untuk memastikan jenis kesalahan yang dilakukan oleh siswa dan untuk mengetahui penyebab kesalahan yang dilakukan oleh siswa dalam menyelesaikan soal persamaan garis lurus. Wawancara dilakukan dengan 3 orang siswa yang terpilih sebagai subjek penelitian.

4. Melakukan wawancara dengan guru.

Analisis data dalam penelitian ini dilakukan dengan langkah-langkah sebagai berikut:

a. Tabulasi/reduksi data

Tabulasi/reduksi data yaitu kegiatan yang mengacu kepada proses mentransformasikan data mentah yang tertulis 
di lapangan, menyeleksi, menyederhanakan dan mengelompokkan data.

Tahap reduksi data dalam penelitian ini meliputi: (a) Melakukan observasi dan menyusun hasil observasi; (b) Mengoreksi hasil pekerjaan siswa yang akan digunakan untuk menentukan subjek penelitian; dan (c) Melakukan wawancara dengan beberapa subjek penelitian dan hasil wawancara tersebut disederhanakan menjadi susunan bahasa yang baik dan rapi.

b. Penyajian data.

Tahap penyajian data dalam penelitian ini meliputi: (a) Menyajikan data hasil observasi; (b) Menyajikan hasil pekerjaan siswa yang telah dipilih sebagai subjek penelitian; dan (c) Menyajikan hasil wawancara yang telah direkam pada hand phone dan atau video.

Dari hasil penyajian data yang berupa pekerjaan siswa dan hasil wawancara dilakukan analisis, kemudian disimpulkan yang berupa data temuan sehingga mampu menjawab permasalahan dalam penelitian ini.

c. Penarikan kesimpulan dan verifikasi

Verifikasi data dan penarikan kesimpulan dilakukan selama kegiatan analisis berlangsung sehin gga diperoleh suatu kesimpulan final. Dengan cara membandingkan hasil pekerjaan siswa dan hasil wawancara maka dapat ditarik kesimpulan tentang jenis kesalahan yang dilakukan siswa dalam menyelesaikan soal persamaan garis lurus.Selain analisis data diatas, menurut Moleong (2004:178), untuk menentukan keabsahan suatu data diperlukan teknik pemeriksaan yang didasarkan atas derajat kepercayaan, keteralihan, ketergantungan dan kepastian, sehingga dalam penelitian ini menggunakan teknik triangulasi. Teknik triangulasi dalam penelitian ini dilakukan dengan penggunaan sumber yaitu dengan membandingkan data hasil tes dan hasil wawancara di tempat dan waktu yang berbeda dari pengumpulan data sebelumnya. Yaitu dengan cara membandingkan data hasil tes dan data hasil wawancara dengan siswa, serta membandingkan dengan hasil wawancara dengan guru.

\section{Hasil dan Pembahasan}

\section{Hasil Analisis Deskriptif}

Data kemampuan siswa dikumpulkan dan dianalisis untuk mengetahui deskripsi kemampuan siswa dalam menyelesaikan soal persamaan garis lurus. Data ini diperoleh dari hasil Tes Persamaan Garis Lurus yang diujikan pada siswa kelas VIII-2 MTsN 2 Kendari yang disajikan lengkap pada Tabel 1.

Tabel 1

Data hasil tes persamaan garis lurus

Berdasarkan Tabel 1 dapat dilihat

\begin{tabular}{|l|l|}
\hline Deskriptif data & Nilai \\
\hline Mean & 38,83 \\
\hline Median & 37 \\
\hline Modus & 23 \\
\hline Range & 52 \\
\hline Standard Deviation & 13,19 \\
\hline Minimum & 14 \\
\hline Maximum & 66 \\
\hline Sum & 1126 \\
\hline Count & 29 \\
\hline
\end{tabular}

bahwa rata-rata hasil tes persamaan garis lurus pada siswa kelas VIII-2 MTsN 2 Kendari adalah 38,83; mediannya adalah 37; Mode (modusnya) adalah 23; standar deviasinya 13,19 dan nilai minimum adalah 14 serta nilai maksimumnya adalah 66 .

\section{Data Hasil Tes}

Tes diberikan kepada siswa setelah seluruh materi selesai diberikan. Berdasarkan hasil pekerjaan siswa dalam mengerjakan soalsoal pada materi persamaan garis lurus, 
ditemukan kesalahan-kesalahan yang dilakukan oleh siswa. Kesalahan-kesalahan tersebut

disajikan pada tabel berikut.

Tabel 2

Deskripsi Kesalahan Siswa

\begin{tabular}{|c|c|c|}
\hline Soal & Deskripsi Kesalahan Siswa & $\begin{array}{c}\text { Jumlah Siswa } \\
\text { (orang) }\end{array}$ \\
\hline 1 & $\begin{array}{l}\text { Siswa salah dalam menulis simbol } \\
\text { Siswa tidak memahami konsep gradien } \\
\text { Siswa salah dalam menerapkan operasi aljabar }\end{array}$ & $\begin{array}{c}1 \\
10 \\
1\end{array}$ \\
\hline 2 & $\begin{array}{l}\text { Siswa tidak memahami apa yang ditanyakan dalam soal } \\
\text { Siswa salah dalam menerapkan rumus untuk mencari gradien persamaan } \\
\text { garis yang melalui dua titik } \\
\text { Siswa salah dalam melakukan perhitungan }\end{array}$ & $\begin{array}{l}4 \\
1 \\
2\end{array}$ \\
\hline 3 & $\begin{array}{l}\text { Siswa salah dalam penulisan simbol } \\
\text { Siswa salah menerapkan rumus persamaan garis } \\
\text { Siswa salah dalam melakukan operasi aljabar } \\
\text { Siswa salah dalam melakukan perhitungan } \\
\text { Siswa tidak menjawab }\end{array}$ & $\begin{array}{c}4 \\
3 \\
25 \\
25 \\
1\end{array}$ \\
\hline 4 & $\begin{array}{l}\text { Siswa tidak memahami apa yang ditanyakan dalam soal } \\
\text { Siswa salah dalam mencari gradien garis lurus } \\
\text { Siswa salah dalam menerapkan rumus untuk mencari persamaan garis } \\
\text { lurus yang melalui satu titik yang telah diketahui gradiennya } \\
\text { Siswa salah dalam melakukan operasi aljabar } \\
\text { Siswa salah dalam melakukan perhitungan } \\
\text { Siswa tidak menjawab }\end{array}$ & $\begin{array}{c}11 \\
2 \\
9 \\
11 \\
11 \\
6\end{array}$ \\
\hline 5 & $\begin{array}{l}\text { Siswa salah menanggapi permintaaan soal } \\
\text { Siswa salah menerapkan rumus untuk mencari gradien garis lurus } \\
\text { Siswa salah dalam melakukan operasi aljabar } \\
\text { Siswa salah dalam melakukan perhitungan } \\
\text { Siswa tidak menyelesaikan jawabannya } \\
\text { Siswa tidak menjawab }\end{array}$ & $\begin{array}{l}1 \\
5 \\
8 \\
11 \\
6 \\
6\end{array}$ \\
\hline 6 & $\begin{array}{l}\text { Siswa salah menggunakan data yang tidak terdapat pada soal } \\
\text { Siswa salah menerapkan rumus untuk mncari gradien garis lurus } \\
\text { Siswa salah dalam melakukan operasi aljabar } \\
\text { Siswa salam dalam melakukan perhitungan } \\
\text { Siswa tidak menjawab }\end{array}$ & $\begin{array}{l}1 \\
5 \\
2 \\
8 \\
9\end{array}$ \\
\hline 7 & $\begin{array}{l}\text { Siswa salah dalam pengerjaan } \\
\text { Siswa salah dalam melakukan perhitungan } \\
\text { Siswa tidak menjawab }\end{array}$ & $\begin{array}{c}21 \\
9 \\
8\end{array}$ \\
\hline
\end{tabular}

\section{Data Hasil Observasi}

Observasi dilakukan pada saat proses pembelajaran materi persamaan garis lurus. Observasi dilakukan sebagai salah satu cara untuk mengumpulkan data. Hasil observasi dapat diuraikan sebagi berikut

1. Metode yang digunakan guru adalah metode ceramah, tanya jawab, dan pemberian tugas.

2. Pada awal pembelajaran, guru menyampaikan tujuan pembelajaran tetapi terkadang guru lupa menyampaikan tujuan pembelajaran.

3. Guru memotivasi siswa di awal pelajaran.

4. Setelah menyampaikan materi, guru selalu memberikan kesempatan kepada siswa untuk bertanya.

5. Guru jarang memberikan penguatan kepada siswa.

6. Guru tidak mengaitkan materi dengan pelajaran yang akan datang. 
7. Buku yang digunakan guru adalah buku yang ada di sekolah yaitu buku BSE.

8. Keaktifan siswa dalam bertanya kepada guru mengenai hal-hal yang belum mereka ketahui sangatlah kurang.

9. Keaktifan siswa dalam menjawab pertanyaan dari gurupun rendah. Siswa akan menjawab pertanyaan, khusus pertanyaanpertanyaan yang membutuhkan jawaban serentak.

10. Pada saat guru meminta siswa mengerjakan soal latihan, ada siswa yang bisa mengerjakannya dengan baik, ada pula yang masih dibimbing oleh guru, dan ada pula siswa yang hanya menunggu jawaban dari teman sebangkunya.

11. Soal latihan yang berbeda dengan contoh soal yang diberikan oleh guru hanya dapat dikerjakan dengan baik oleh 5 orang siswa dari 32 orang siswa.

12. Untuk soal latihan yang tidak selesai dikerjakan di sekolah, guru selalu mengingatkan siswa agar mengerjakan di rumah.

13. Ketika ditanya oleh guru tentang latihan yang dikerjakan dirumah, hanya beberapa orang siswa yang mengerjakan latihan soal dari 32 orang siswa yang ada.

\section{Analisis Data}

Berikut ini akan disajikan beberapa kesalahan siswa dalam menyelesaikan soal-soal persamaan garis lurus. Dalam penelitian ini diambil 3 siswa yang dianalisis jawabannya.

Analisis Kesalahan Jawaban Siswa S-02

Soal nomor 2

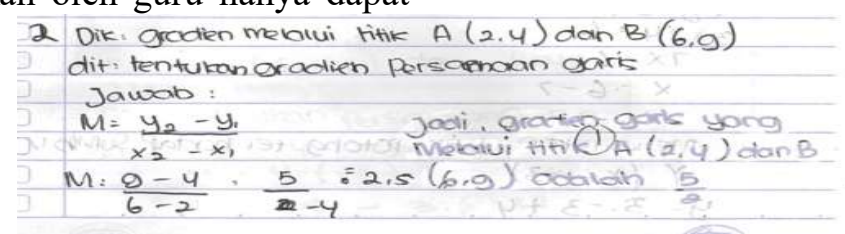

Gambar 1

Jawaban nomor 2 siswa S-02

Berdasarkan Gambar 1 di atas dapat dilihat bahwa salah menuliskan apa yang diketahui dalam soal, dan tampak bahwa siswa menulis hasil operasi $6-2$ adalah -4 seharusnya 4 sehingga gradien yang diperoleh siswa tersebut $\frac{5}{-4}$ seharusnya $\frac{5}{4}$. Kemudian siswa melakukan pembagian terhadap bilangan pecahan tersebut dan memperoleh hasil 2,5 seharusnya $-1,25$.

Untuk menelusuri lebih lanjut mengenai kesalahan siswa, peneliti melakukan wawancara dengan hasil bahwa siswa S-02 siswa kurang teliti dalam perhitungannya.

Soal nomor 4

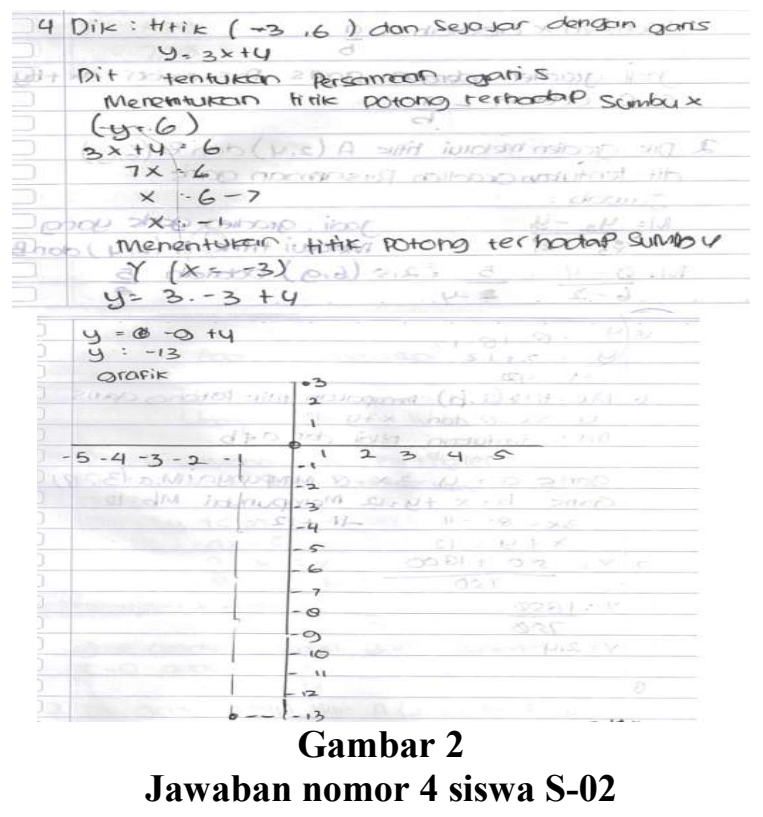


Berdasarkan jawaban siswa pada gambar di atas dapat dilihat bahwa siswa salah dalam menanggapi permintaan soal dimana dalam soal diminta untuk mencari persamaan garis yang melalui titik $(-3,6)$ dan sejajar garis y $=3 \mathrm{x}+4$. Namun dalam jawaban, siswa mencari titik potong garis $\mathrm{y}=3 \mathrm{x}+4$ terhadap sumbu $\mathrm{x}$ dengan mensubstitusi $\mathrm{y}=6$ ke persamaan $\mathrm{y}=3 \mathrm{x}$ +4 .

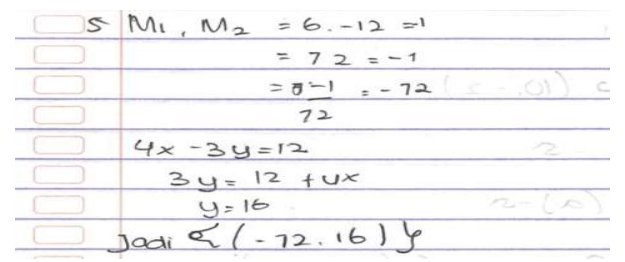

Gambar 3

Jawaban nomor 5 siswa S-02

Berdasarkan jawaban siswa pada gambar di atas dapat dilihat bahwa siswa salah menanggapi permintaan soal dan salah dalam memasukkan data yang telah diketahui. Titik (6, -12) dianggap siswa adalah gradient dari masing-masing garis. Dimana $\mathrm{m}_{1}=6$ dan $\mathrm{m}_{2}=$ 12. Seharusnya gradien dari garis $4 x-3 y=12$ adalah $\mathrm{m}_{1}=\frac{-4}{-3}=\frac{4}{3}$. Karena dua garis saling tegak lurus maka $\mathrm{m}_{1} \times \mathrm{m}_{2}=-1$, maka untuk memperoleh $\mathrm{m}_{2}$ seharusnya melakukan operasi pembagian terhadap -1 oleh $\mathrm{m}_{1}$ maka dipeoleh $\mathrm{m}_{2}=-\frac{3}{4}$. Siswa juga melakukan kesalahan operasi aljabar pada persamaan garis $4 \mathrm{x}-3 \mathrm{y}$
Untuk menelusuri lebih lanjut mengenai kesalahan siswa, peneliti melakukan wawancara dengan hasil bahwa siswa S-02 salah menanggapi permintaan soal dan siswa kurang memeahami langkah -langkah untuk mencari persamaan garis yang melalui sebuah titik dan sejajar dengan garis lain.

\section{Soal nomor 5}

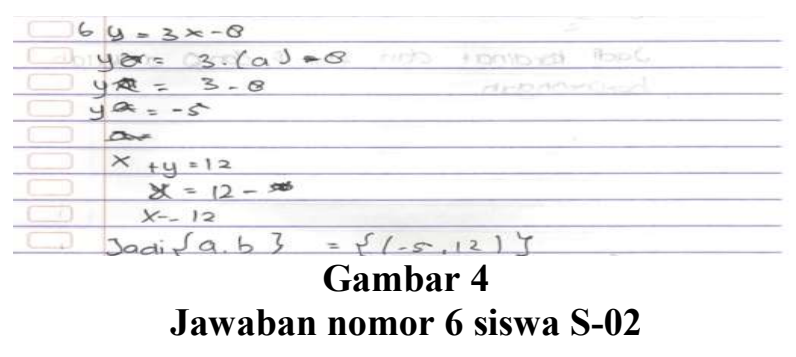

Berdasarkan jawaban siswa pada Gambar 4 di atas dapat dilihat bahwa pada penyelesaian jawaban siswa tidak memahami maksud dari permintaan soal dimana titik $(a, b)$ merupakan titik potong kedua garis yang telah diketahui. Dalam penyelesaian soal siswa mensubstitusi a ke persamaan $\mathrm{y}=3 \mathrm{x}-8$ menjadi $y=3$. (a) -8 dan melakukan kesalahan dalam operasi aljabar sehinnga memperoleh $\mathrm{y}=$ $3-8, y=-5$. Kemudian menuliskan $\mathrm{x}+\mathrm{y}=12$,
$=12$ dan kemudian menemukan hasil akhir yang menggambarkan sebuah titik..

Untuk menelusuri lebih lanjut mengenai kesalahan siswa, peneliti melakukan wawancara dengan hasil bahwa siswa S-02 tidak mengingat rumus mencari gradien persamaan garis ax + by $+\mathrm{c}=0$, Dan tidak mengingat sifat dua garis yang saling tegak lurus dan langkah-langkah penyelesaian dalam mencari persamaan garis yang melalui sebuah titik dan tegak lurus garis lain. Tidak hanya itu, siswa juga kurang memahami konsep persamaan dan operasi aljabar serta bilangan pecahan.

\section{Soal nomor 6}

\section{4}


$\square \frac{750}{50}=15^{\square} M=\frac{15}{30}=2 \mathrm{kM}$

Gambar 5

Jawaban nomor 7 siswa S-02

Berdasarkan jawaban siswa pada Gambar 5 di atas dapat dilihat bahwa siswa tidak memahami cara menyelesaikan soal tersebut. Hal ini tampak pada jawaban siswa yang kurang jelas langkah penyelesaiannya. Siswa langsung menuliskan jawaban, tanpa menuliskan apa sebenarnya yang akan di cari. Selain itu, dalam penyelesaian soal siswa salah menuliskan rumus, dan siswa salah dalam melakukan perhitungan.

Untuk menelusuri lebih lanjut mengenai kesalahan siswa, peneliti melakukan wawancara dengan hasil bahwa siswa S-02 tidak mengetahui langkah-langkah penyelesaian soal.

a. Analisis Kesalahan Jawaban Siswa S-09

Soal Nomor 1

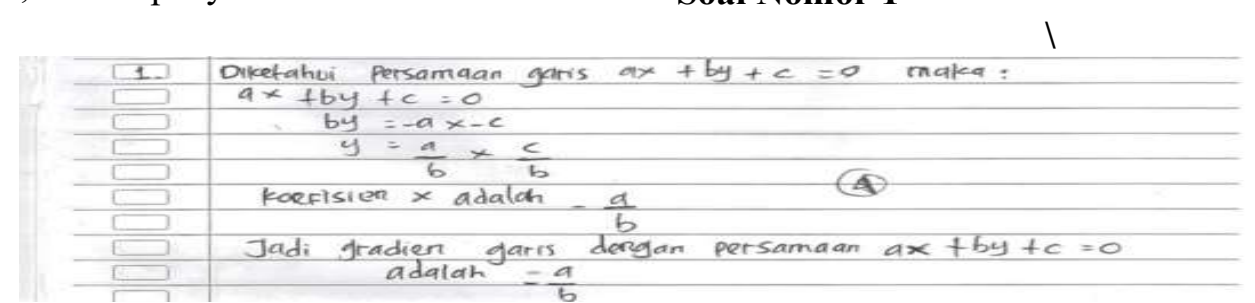

Gambar 6

Jawaban nomor 1 siswa S-09

Berdasarkan jawaban siswa pada Gambar 6 di atas dapat dilihat bahwa pada penyelesaian siswa menuliskan $\mathrm{y}=\frac{\mathrm{a}}{\mathrm{b}} \mathrm{x} \frac{\mathrm{c}}{\mathrm{b}}$ seharusnya $\mathrm{y}=-\frac{\mathrm{a}}{\mathrm{b}} \mathrm{x}-\frac{\mathrm{c}}{\mathrm{b}}$.

Untuk menelusuri lebih lanjut mengenai kesalahan siswa, peneliti melakukan wawancara dengan hasil bahwa siswa S-09 kurang memahami konsep persamaan dalam menyelesaikan soal dengan menghilangkan tanda (-) masing-masing bilangan pada ruas kanan baris ketiga, dan lupa bahwa $\mathrm{x}$ yang dimaksud adalah sebuah variabel dari koefisien $-\frac{\mathrm{a}}{\mathrm{b}}$ sehingga pada saat wawancara siswa menyebutkan bahwa $\mathrm{x}$ adalah tanda perkalian.

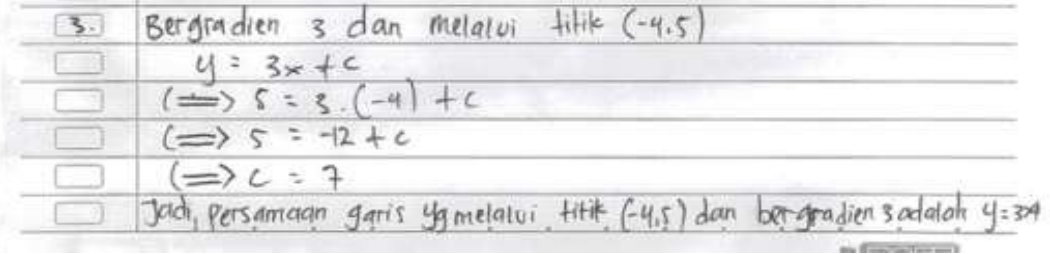

Gambar 7

Jawaban nomor 3 siswa S-09

Berdasarkan jawaban siswa pada Gambar 7 di atas dapat dilihat bahwa siswa menuliskan hasil dari c adalah 7, seharusnya 17 .

Untuk menelusuri lebih lanjut mengenai kesalahan siswa, peneliti melakukan wawancara dengan hasil bahwa kerana siswa kurang teliti dalam perhitungannya.

Soal nomor 4 


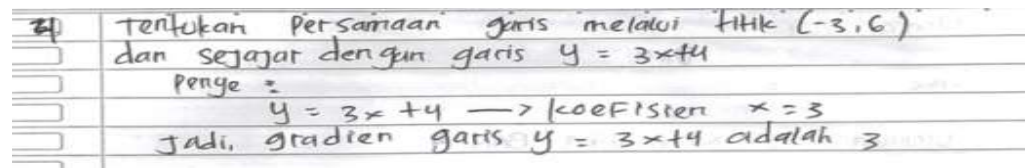

\section{Gambar 8}

\section{Jawaban nomor 4 siswa S-09}

Berdasarkan jawaban siswa pada Gambar 8 di atas dapat dilihat bahwa siswa salah dalam menanggapi permintaan soal, penyelesaian siswa dalam menjawab soal nomor 4 terhenti pada pencarian gradient garis $\mathrm{y}$ $=3 \mathrm{x}+4$.
Untuk menelusuri lebih lanjut mengenai kesalahan siswa, peneliti melakukan wawancara dengan hasil bahwa siswa S-09 tidak memahami konsep mencari persamaan garis yang sejajar garis lain dan melalui sebuah titik.

Soal nomor 5

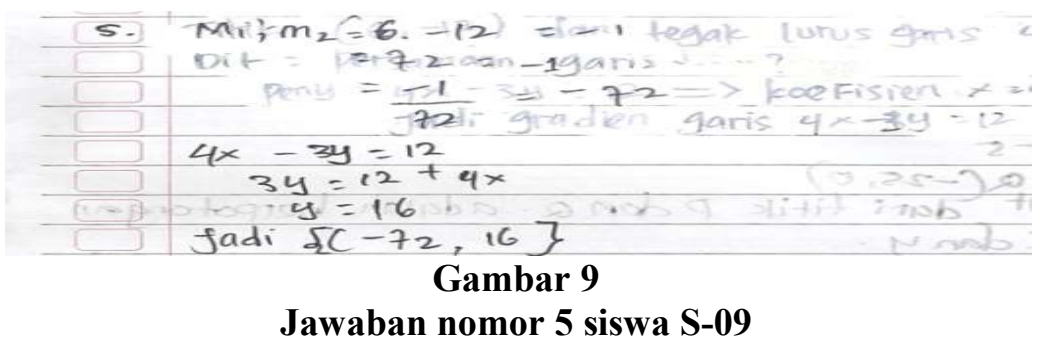

Berdasarkan jawaban siswa pada gambar di atas dapat dilihat bahwa siswa salah menanggapi permintaan soal dan salah dalam memasukkan data yang telah diketahui. Titik (6, -12) dianggap siswa adalah gradient dari masing-masing garis. Dimana $\mathrm{m}_{1}=6$ dan $\mathrm{m}_{2}=$ 12. Seharusnya gradien dari garis $4 x-3 y=12$ adalah $\mathrm{m}_{1}=\frac{-4}{-3}=\frac{4}{3}$. Karena dua garis saling tegak lurus maka $\mathrm{m}_{1} \times \mathrm{m}_{2}=-1$, maka untuk memperoleh $\mathrm{m}_{2}$ seharusnya melakukan operasi pembagian terhadap -1 oleh $m_{1}$ maka dipeoleh $\mathrm{m}_{2}=-\frac{3}{4}$. berdasarkan jawaban siswa melakukan kesalahan operasi aljabar pada persamaan garis $4 \mathrm{x}-3 \mathrm{y}=12$ dan kemudian menemukan hasil akhir yang menggambarkan sebuah titik.

Untuk menelusuri lebih lanjut mengenai kesalahan siswa, peneliti melakukan wawancara dengan hasil bahwa siswa S-09 melupakan syarat dua garis saling tegak lurus. Siswa juga masih kurang teliti dalam memasukkan data ke dalam rumus. Tidak hanya itu siswa masih melakukan kesalahan dalam proses perhitungan dan dalam penulisan operasi pengurangan oleh bilangan bulat negatif.

\section{Soal nomor 6}

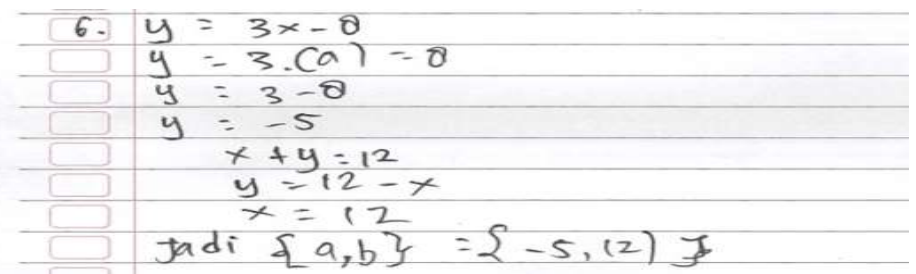

Gambar 10

Jawaban nomor 6 siswa S-09

Berdasarkan jawaban siswa pada Gambar 10 di atas dapat dilihat dalam penyelesaian soal siswa mensubstitusi a ke persamaan $y=3 x-8$ menjadi $y=3$. (a) -8 dan melakukan kesalahan dalam operasi aljabar sehingga memperoleh $\mathrm{y}=3-8, \mathrm{y}=-5$.
Kemudian menuliskan $\mathrm{x}+\mathrm{y}=12, \mathrm{x}=12$ sehingga siswa tersebut memperoleh titik potong $(-5,12)$.

Untuk menelusuri lebih lanjut mengenai kesalahan siswa, peneliti melakukan wawancara dengan hasil bahwa siswa S-09 lupa cara 
menyelesaikan soal mengenai titik potong dua Soal nomor 7

garis.

$7 . \frac{750}{50}=15 \mathrm{~m}=\frac{15}{30}=2 \mathrm{~km}$
Gambar 11
Jawaban nomor 7 siswa S-09

Berdasarkan jawaban siswa pada Gambar $11 \mathrm{di}$ atas dapat dilihat siswa melakukan kesalahan dalam lengkah-langkah menyelesaikan soal dan siswa salah dalam melakukan perhitungan.

Untuk menelusuri lebih lanjut mengenai kesalahan siswa, peneliti melakukan wawancara dengan hasil bahwa siswa S-09 kurang memahami langkah-langkah dalam menyelesaikan soal. Pada langkah awal siswa melakukannya dengan benar namun saat

diwawancara siswa tidak mengetahui tujuan dari pekerjaannya.

b. Analisis Kesalahan Jawaban Siswa S-17 Soal nomor 1

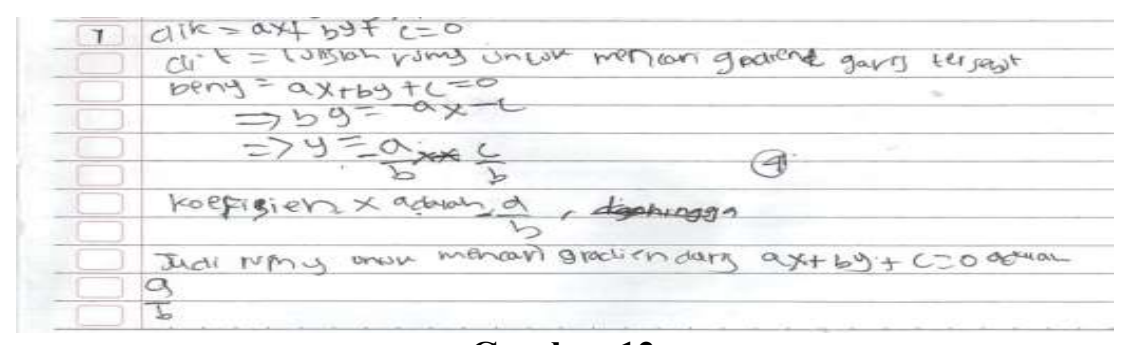

\section{Gambar 12 \\ Jawaban nomor 1 siswa S-17}

Berdasarkan jawaban siswa pada Gambar 12 di atas dapat dilihat bahwa siswa menuliskan $\mathrm{y}=\frac{\mathrm{a}}{\mathrm{b}} \mathrm{x}-\frac{\mathrm{c}}{\mathrm{b}}$ seharusnya $\mathrm{y}=$ $-\frac{\mathrm{a}}{\mathrm{b}} \mathrm{x}-\frac{\mathrm{c}}{\mathrm{b}}$.
Untuk menelusuri lebih lanjut mengenai kesalahan siswa, peneliti melakukan wawancara dengan hasil bahwa siswa S-17 kurang teliti dalam menjawab soal.

Soal nomor 3

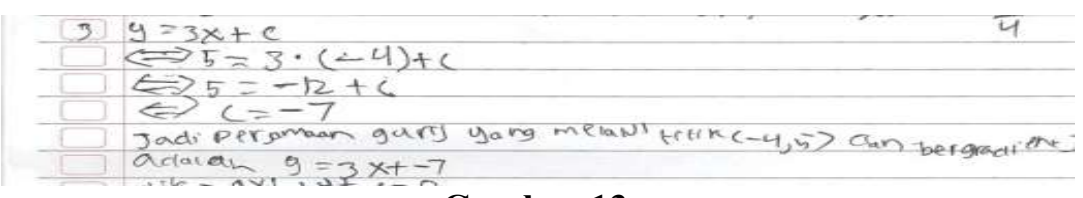

Gambar 13

Jawaban nomor 3 siswa S-17

Berdasarkan jawaban siswa pada Gambar 13 di atas dapat dilihat bahwa siswa tersebut menuliskan $\mathrm{y}=3 \mathrm{x}+\mathrm{c}$ yang kemudian mensubstitusikan nilai dari titik $(-4,5)$ menjadi $5=3(-4)+\mathrm{c}$, seharusnya rumus yang digunakan adalah $\mathrm{y}-\mathrm{y}_{1}=\mathrm{m}\left(\mathrm{x}-\mathrm{x}_{1}\right)$, dimana ($4,5)=\left(x_{1}, y_{1}\right)$ sehingga $y-5=3(x-(-4)$. Kesalahan berlanjut pada baris 3 dan 4 sehingga siswa memperoleh $\mathrm{c}=-7$, sehingga siswa menuliskan persamaan yang diperolehnya adalah $y=3 x+-7$. Dari persamaan yang siswa peroleh pun seharusnya $y=3 x+(-7)$ atau $y=3 x$ $-7$.

Untuk menelusuri lebih lanjut mengenai kesalahan siswa, peneliti melakukan wawancara dengan hasil bahwa siswa S-17 tidak memahami konsep persamaan.

Soal nomor 4 


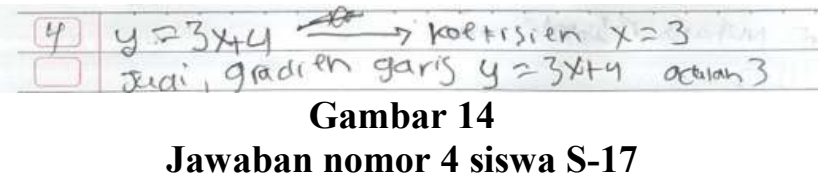

Berdasarkan jawaban siswa pada Gambar 14 di atas dapat dilihat bahwa siswa salah menanngapi permintaan soal dimana dalam soal siswa diminta untuk mencari persamaan garis yang melalui sebuah titik dan sejajar dengan sebuah garis. Namun dalam penyelesaiannya siswa hanya mencari gradient garis yang diketahui.

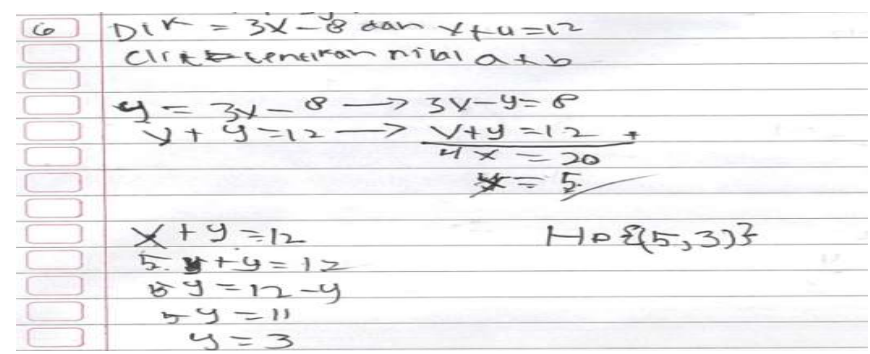

Gambar 15

Jawaban nomor 6 siswa S-17

Berdasarkan jawaban siswa pada Gambar 15 di atas dapat dilihat bahwa pada baris ke 6 siswa menuliskan $5+\mathrm{y}=12$ lalu pada baris ke 7 siswa menuliskan $5 \mathrm{y}=12-\mathrm{y}$. seharusnya $\mathrm{y}=12-5$. Lalu pada baris ke 8 , siswa menuliskan $5 \mathrm{y}=11$, lalu memperoleh $\mathrm{y}=$ 3. Tidak hanya kesalahan dalam operasi aljabar, siswa juga salah dalam proses perhitungan.
Untuk menelusuri lebih lanjut mengenai kesalahan siswa, peneliti melakukan wawancara dengan hasil bahwa siswa S-17 salah dalam menanggapi permintaan soal.

Soal nomor 6

$$
7 \frac{56+750}{30}=\frac{800}{30}=800-30=770
$$

\section{Gambar 16}

\section{Jawaban nomor 7 siswa S-17}

Berdasarkan jawaban siswa pada Gambar 16 di atas dapat dilihat bahwa siswa salah dalam langkah-langkah menyelesaikan soal. Hal ini tampak bahwa siswa menjumlahkan waktu 50 detik dan jarak $750 \mathrm{~m}$ kemudian dibagi 30. Sehingga diperoleh $\frac{50+750}{30}=\frac{800}{30}$. Langkah selanjutnya siswa menulis $800-30=$ 770. Seharusnya siswa mencari jarak tempuh dalam 1 detik yaitu dengan melakukan operasi pembagian terhadap $750 \mathrm{~m}$ oleh 50 dektik, sehingga diperoleh dalam waktu 1 detik mobil melaju sejauh $15 \mathrm{~m}$. kemudian mencari jarak tempuh dalam waktu 30 menit dengan mengubah menit ke detik yaitu 30 x $60=1800$ detik. Sehinnga diperoleh jarak tempuh dalam waktu 30 menit adalah $15 \mathrm{~m} \mathrm{x} 1800=27000 \mathrm{~m}=$ $27 \mathrm{~km}$

Untuk menelusuri lebih lanjut mengenai kesalahan siswa, peneliti melakukan wawancara dengan hasil bahwa siswa S-17 tidak memahami langkah-langkah dalam menyelesaikan soal tersebut.

\section{Analisis Hasil Wawancara dengan Guru}

Berdasarkan hasil wawancara dengan guru diperoleh sebagai berikut:

1. Siswa kurang termotivasi untuk mempelajari materi persamaan garis lurus. Untuk memotivasi siswa, guru mengatakan bahwa 
materi ini selalu muncul dalam soal ujian nasional dan ulangan semesternya.

2. Metode mengajar yang diterapkan oleh guru adalah metode ceramah, tanya jawab, dan pemberian tugas.

3. Siswa masih kesulitan dalam memahami materi persamaan garis lurus dan siswa juga kurang memahami konsep persamaan garis lurus dan materi prasyarat dan sebagainya.

4. Upaya yang dilakukan guru untuk mengatasi kesulitan siswa tersebut adalah mengulang materi yang dipelajari sebelumnya, menjelaskan kembali jika ada siswa yang belum paham, dan dengan memberikan latihan dan juga tugas.

\section{Pembahasan}

Berdasarkan hasil penelitian, jenis-jenis kesalahan yang dilakukan siswa dalam menyelesaka soal garis singgung persekutuan dua lingkaran adalah sebagai berikut:

1. Kesalahan menginterpretasi bahasa

Kesalahan menginterpretasi bahasa yang dilakukan siswa dalam menyelesaikan soal persamaan garis lurus adalah kesalahan dalam menanggapi permintaan soal. Berdasarkan hasil tes, siswa S-02, S-09 dan S-17 salah dalam menanggapi maksud permintaan soal nomor 4 . Dalam soal tersebut siswa diminta untuk menentukan persamaan garis yang melalui sebuah titik dan sejajar garis lain. Namun dalam penyelesaiannya siswa hanya mencari gradient garis $\mathrm{y}=3 \mathrm{x}+4$. Berdasarkan hasil wawancara dengan guru, ini disebakan karena siswa kurang teliti dalam membaca permintaan soal.

2. Kesalahan konsep

Kesalahan konsep yang dilakukan siswa dalam menjawab soal persamaan garis lurus adalah kesalahan dalam menulis rumus untuk mencari gradien persamaan garis, kesalahan dalam menulis rumus mencari persamaan garis, kesalahan dalam mensubstitusi nilai gradient garis yang saling tegak lurus, kesalahan dalam langkah-langkah mencari titik potong dua buah garis dan tidak memahami pengaplikasian persamaan garis lurus dalam kehidupan seharihari. Berdasarkan hasil tes S-02, S-09, S-17 melakukan kesalahan tersebut.

Berdasarkan hasil wawancara tes pada soal nomor 4, S-02, S-09 dan S-17 tidak memahami bagaimana mencari persamaan garis yang melaui sebuah titik sejajar garis lain. S-02 pada jawabannya salah dalam menanggapi permintaan soal, namun saat ditanyakan langkah-langkah yang benar dalam menyelesaikan soal tersebut S-02 belum paham. Sedangkan S-09 dan S-17 hanya mencari gradien garis yang terdapat pada soal dan tidak mengetahui langkah selanjutnya dalam menyelesaikan soal ini. Berdasarkan hasil wawancara guru, guru menyatakan bahwa siswa salah menanggapi permintaan soal atau siswa lupa cara menyelesaikan soal tersebut.

S-02 dan S-05 tidak memahami langkah-langkah dalam penyelesaian soal nomor 5. Dalam jawaban mereka, mereka menganggap bahwa titik yang diketahui dalam soal adalah gradient dari masing-masing garis yang saling tegak lurus., yang kemudian dalam hasil akhir jawaban mereka, mereka memperoleh sebuah titik yang baru. Pada saat wawancara tes, S-02 dan S-09 masih salah dalam mencari gardien garis yang diketahui. Berdasarkan wawancara dengan guru, guru menyatakan bahwa siswa kurang paham cara menyelesaikan soal dan ingat syarat-syarat garis tegak lurus.

Siswa melakukan kesalahan dalam penyelesaian soal mengenai titik potong dua garis. Berdasarkan jawaban tes soal nomor 6, S02 dan S-09, mereka melakukan kesalahan dalam mensubstitusi dan kesalahan dalam operasi aljabar. Berdasarkan wawancara tes dan wawancara guru, siswa tidak memahami langkah-langkah penyelesaian soal.

Siswa tidak memahami pengaplikasian persamaan garis lurus dalam soal kecepatan gerak benda. Berdasarkan jawaban tes nomor 7, S-02 dan S-09 melakukan kesalahan dalam langkah kedua dan seterusnya. Sedangkan S-17 melakukan kesalahan dalam setiap langkah penyelesaian soal. Berdasarkan hasil wawancara tes, S-02 dan S-09 tidak mengetahui tujuan dari langkah pertama yang ditulisnya dan tidak mengetahui langkah apa yang harus dilakukan selanjutnya, begitu pula S-17. Namun, saat diberikan contoh soal lain yang lebih sederhana mereka mampu menjawabnya. Berdasarkan hasil wawancara dengan guru, S-02 tidak mengetahui langkah selanjutnya sedangkan S-09 dan S-17 tidak memahami cara penyelesaian soal tersebut,

3. Kesalahan Prinsip

Kesalahan prinsip yang dilakukan siswa dalam menyelesaikan soal persamaan garis lurus 
adalah kesalahan dalam menerapkan rumus persamaan garis lurus, kesalahan dalam mencari persamaan garis yang melalui sebuah titik dan sejajar garis lain, kesalahan dalam mencari sebuah garis yang melalui sebuah titik san tegak lurus garis lain, kesalahan dalam mencari titik potong dua buah garis, kesalahan dalam langkalangkah penyelesaian soal aplikasi persamaan garis lurus dalam kehidupan sehari-hari.

Kesalahan dalam mencari persamaan garis yang melalui sebuah titik dan tegak lurus garis lain dilakukan oleh S-02 dan S-09. Berdasarkan jawaban tes, siswa melakukan kesalahan dalam memasukkan nilai titik yang seharusnya dilalui oleh garis yang dicari menjadi gradient masing-masing garis. Berdasarkan wawancara, siswa masih melakukan kesalahan dalam mencari gradient garis yang diketahui yang kemudian hasil itu dapat digunakan untuk mencari gradient garis yang akan dicari. Berdasarkan wawancara guru, hal ini dikarenakan siswa masih kurang memahami langkah-langkah penyelesaian soal.

Siswa melakukan kesalahan dalam mencari titik potong dua garis,. Berdasarkan hasil tes soal nomor 6, S-02 dan S09 salah dalam langkah-langkah penyelesaian soal. S-09 melakukan kesalahan dengan menuliskan gradien garis layaknya sebuah titik, sedangkan S-09 salah mensubstitusi nilai ke pesamaan garis. Berdasarkan hasil wawancara, siswa tidak memahami langkah-langkah penyelesaian soal hal ini sejalan dengan hasil wawawancara guru

Siswa melakukan kesalahan dalam soal pengaplikasian persamaan garis lurus dalam kehidupan sehari-hari. Berdasarkan hasil tes S02, S-09, S-17 tidak memahami pengabungan konsep kecepatan gerak benda dan konsep pengukuran. Dalam jawaban S-02 dan S-09 mereka tidak memahami langkah mencari jarak tempuh mobil selama 30 menit, diman setelah mendapat jarak satu detik, jarak tersebut harus dikali oleh 1800 (1800 = 30 menit), bukan dibagikan oleh 30. Sedangkan S-17 telah melakukan kesalahan sejak langkah pertama.

Berdasarkan wawancara ketiga siswa tersebut sebenarnya mampu untuk menyelesaikan soal apabila diberikan contoh soal yang lebih sederhana. Berdasrkan wawancara guru, hal ini dikarenakan daya nalar siswa yang masih kurang.

4. Kesalahan Keterampilan
Kesalahan keterampilan yang dilakukan siswa dalam menyelesaikan soal persamaan garis lurus adalah kesalahan dalam perhitungan bilangan bulat, kesalahan dalam mengubah pecahan ke decimal, kesalahan operasi aljabar.

Berdasarkan hasil tes, kesalahan dalam operasi perhitungan bilangan bulat dilakukan oleh S-02 pada saat mencari gradient garis soal nomor 2. Siswa menulis 6-2 adalah -4 . Tidak hanya itu S-02 juga melakukan kesalahan dalam mengubah pecahan ke desimal. Pada jawaban tes nomor 2 siswa menulis $\frac{5}{-4}=2,5$, seharusnya $-1,25$. Berdasarkan wawancara, ini dikarenakan siwa kurang teliti dalam perhitungannya. Hal ini sejalan dengan yang dikatakan guru dalam wawancara.

Kesalahan operasi aljabar dilakukan oleh S-02 dan S-09. Berdasarkan hasil tes siswa menulis $3 y=12+4 x$ kemudian $y=16$. Siswa menjumlahkan 12 dan 4 tanpa memperhatikan variabel $\mathrm{x}$ yang menunjukkan bahwa keduanya tidak bisa dijumlahkan, dan $3 y$ menjadi $y$. Berdasarkan wawancara siswa tidak teliti dalam perhitungannya hal ini sejalan dengan hasil wawancara terhadap guru.

\section{Simpulan dan Saran Simpulan}

Berdasarkan hasil analisis dan pembahasan dalam penelitian ini, maka dapat disimpulkan sebagai berikut:

1. Jenis kesalahan yang dilakukan siswa kelas VIII-2 MTs Negeri 2 Kendari dalam menyelesaikan soal persamaan garis lurus adalah kesalahan menginterpretasi bahasa, kesalahan konsep, kesalahan prinsip, dan kesalahan dalam keterampilan.

2. Penyebab siswa melakukan kesalahan dalam menyelesaikan soal persamaan garis lurus adalah siswa tidak memahami konsep, siswa tidak dapat menggabungkan konsep-konsep yang diperlukan dalam menyelesaikan soal, faktor keteledoran siswa, siswa tidak memahami maksud soal dan langkahlangkah untuk menyelesaikan soal.

\section{Saran}

Berdasarkan hasil penelitian, maka penulis memberikan beberapa saran sebagai berikut: 
1. Dalam mengajarkan matematika hendaknya tidak semata-mata ditujukan pada keterampilan peserta didik dalam menyelesaikan soal. Namun yang lebih penting adalah bagaimana caranya mengajak peserta didik untuk memahami dan mengerti serta menguasai konsep-konsep yang ada secara baik dan benar, sehingga peserta didik tidak mengalami kesulitan dalam menyelesaikan soal-soal panjang garis singgung persekutuan dua lingkaran.

2. Sebaiknya siswa tidak hanya diarahkan untuk menghafal rumus yang ada saja, tetapi juga harus memahami konsep dari rumus tersebut.

3. Untuk menghindari kesalahan akibat ketidaktelitian yang dilakukan siswa, sebaiknya dalam proses pembelajaran siswa dibiasakan untuk memeriksa kembali jawabannya.

\section{Daftar Pustaka}

Biklen S.K. ,Bogdan, dan Robert C. (1982) Qualitative Research in Education. Boston : Allyn \& Bacon, inc.

Budiyono.(2003). Statistika Dasar. Surakarta : UNS Press.

Dris, J, Tasari. (2011). MATEMATIKA Jilid 2untuk SMP dan MTS kelas VIII. Jakarta: Kementrian Pendidikan Nasional.
Fathani, Abdul Hakim. (2009). Matematika Hakikat dan Logika. Jogyakarta: ArRuzz Media.

Gagne, R.M. (1983). Some issues in the Psychology oh Mathematics Instruction. Journal for Research in Mathematics Education.

Moleong, L.J. (2004). Metodologi Penelitian Kualitatif. Bandung: Remaja Rosdakarya.

Rahaju, Endah Budi, dkk. (2008). Contextual Teaching and Learning Matematika: SMP/MTs Kelas VIII Edisi 4. Jakarta: Departemen Pendidikan Nasional.

Shadiq, F dan Nur Amini Mustajab. (2011). Penerapan Teori Belajar dalam Pembelajaran Matematika di SD. Yogyakarta: Kementerian Pendidikan Nasional Badan Pengembangan Sumber Daya Manusia Pendidikan dan Penjaminan Mutu Pendidikan.

Sudaryono. (2012). Dasar-Dasar Evaluasi Pembelajaran. Yogyakarta: Graha Ilmu.

Sudijono, Anas. (2006). Pengantar Statistik Pendidikan. Jakarta: PT. Raja Grafindo Persada

Sudjana, Nana. (2008). Penilaian Hasil Proses Belajar Mengajar. Bandung: Remaja Rosdakarya. 